\title{
Current Status and Future Prospects of Soybean Production in Kazakhstan
}

\author{
Akbota Makulbekova ${ }^{1}$, Ayup Iskakov ${ }^{2}$, Krishnanand P. Kulkami', Jong Tae Song ${ }^{1}$, Jeong-Dong Lee ${ }^{1,3} *$ \\ ${ }^{1}$ School of Applied Biosciences, Kyungpook National University, Daegu 41566, Korea \\ ${ }^{2}$ North Kazakhstan Research Institute of Livestock and Crop Production, Petropavlovsk 150700, Kazakhstan \\ ${ }^{3}$ Institute of Agricultural Science \& Technology, Kyungpook National University, Daegu 41566, Korea
}

\begin{abstract}
Kazakhstan is an agrarian country with 270 million hectares utilized for animal and crop production. The foremost objective of the state agriculture programs in Kazakhstan is to achieve food security of country on the basis of competitive crop production. Demand for soybean as an oil crop and animal feed is steadily growing in Kazakhstan and hence soybeans can be a great attribute for food security in this region. Currently, over $90 \%$ of all soybean production is concentrated in one region (Almaty) because the crop is highly sensitive to photoperiod and temperature. The climatological conditions in majority of the region pose difficulties in growing the soybeans. In this review, we discussed the impact of the geographical and environmental conditions in enhancing the soybean cultivation in different parts of Kazakhstan. Additionally, we have taken an account of current status of soybean production and the barriers that may have great influence on the soybean yield. Because soybean is a short-day plant, the main role in its adaptation to areas in Kazakhstan is played by its $E$ genes (maturity and flowering genes), the exploitation of which constitutes the primary challenge for the expansion of soybean cultivation. Besides, we have proposed candidate regions for soybean expansion, including Almaty, Zhambyl (south), East Kazakhstan and Kostanay (north). Expanding soybean production in Kazakhstan and in Central Asia could be addressed using competitive education, application of modern scientific methods and cutting-edge breeding technologies, appropriate financing, and productive strategies to develop superior cultivars with tolerance to abiotic stresses.
\end{abstract}

Keywords Soybean, Kazakhstan, Maturity, Soil salinization, Genetic resources

\section{GEOGRAPHICAL FEATURE OF KAZAKHSTAN}

Kazakhstan is located at the junction of two continents, Europe and Asia, between $45^{\circ}$ and $87^{\circ} \mathrm{E}$, and $40^{\circ}$ and $55^{\circ} \mathrm{N}$. The country has substantial land resources covering 2,700,000 $\mathrm{km}^{2}$ (The World Bank 2015a). Kazakhstan shares borders with Russia to the north and west, China to the east, and Kyrgyzstan, Uzbekistan, and Turkmenistan to the south. Kazakhstan is the largest country in the world that has no direct access to World Ocean (IPhO 2014). Administratively, Kazakhstan is comprised of 14 regions (Fig. 1), each of which has its own climatic, natural, and soil properties.

The territory of Kazakhstan is distant from oceans and is affected by winds from the west and north. Because of this, the basic climate is extremely continental, with uneven distribution of natural precipitation (Didorenko and Kudaibergenov 2014a). The main feature of a continental climate is that $60-80 \%$ of the annual precipitation falls during the warm period (May-October). Therefore, the main indexes to the quality of agricultural land are land productivity and stability of agricultural indicators. Kazakhstan has distinctive climate during all four seasons, with spring and autumn passing into hot summers and cold winters, respectively. The cropping period is limited to one

Received April 3, 2017; Revised May 2, 2017; Accepted May 11, 2017; Published June 1, 2017

*Corresponding author Jeong-Dong Lee, jdlee@knu.ac.kr, Tel: +82-53-950-5709, Fax: +82-53-958-6880 


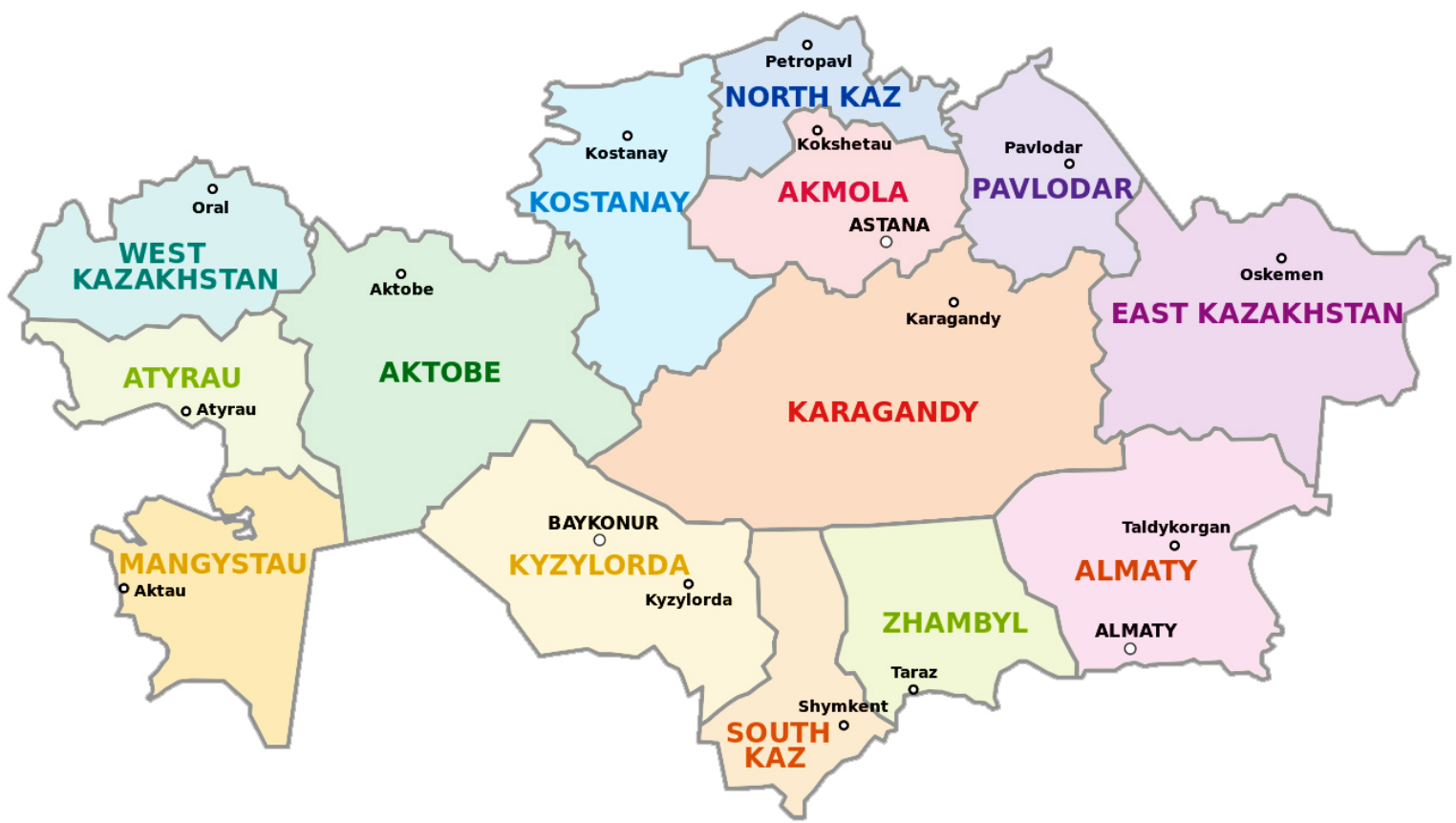

Fig. 1. Regional map of Kazakhstan (Wikipedia https://en.wikipedia.org/wiki/File:Kazakhstan_provinces_and_province_capitals.svg).

harvest per year. The northern region has an average temperature of $19^{\circ} \mathrm{C}$ in summer and $-18^{\circ} \mathrm{C}$ in winter, whereas the southern region has an average temperature of $29^{\circ} \mathrm{C}$ in summer and $-3^{\circ} \mathrm{C}$ in winter (Ministry of Energy of the Republic of Kazakhstan 2015). The frost-free period in Kazakhstan varies between 130-135 days in the north, and 245-275 days in the south. The cultivation period for crops extends from March to October in the south, and from April to September in the north. Annual precipitation fluctuates from $100 \mathrm{~mm}$ to $1,600 \mathrm{~mm}$ (Frenken 2012). Insufficient precipitation together with strong winds causes high evapotranspiration rates, which necessitates additional irrigation for sustainable crop production in most areas of the country. The vast territory of Kazakhstan is split into natural zones and subzones: a moderately wet forest steppe zone with grey forest soils (North Kazakhstan); moderately arid and arid steppe zones with black soils (Aktobe, Kostanay, North Kazakhstan, Akmola, Pavlodar, and East Kazakhstan); moderately dry, dry, and desert-steppe zones with chestnut soils (West Kazakhstan, Aktobe, Kostanay, Akmola, Pavlodar, East Kazakhstan, and Karagandy); and a desert zone with brown and gray-brown soils (Atyrau, Aktobe, Mangystau, Karagandy, East Kazakhstan, Kyzylorda, South Kazakhstan, Zhambyl, and Almaty)
(Saparov 2014). The desert zone constitutes $80 \%$ of all the land resources (Frenken 2012). The elevation of land changes from east Altai, northeastern Zhongar Alatau, and the Tien Shan Mountains (4,000-5,000 m) to the Caspian lowlands (below sea level) (OCHA 2012).

\section{AGRO-PRODUCTION OF KAZAKHSTAN}

Kazakhstan defines itself as an agrarian country with 220 million hectares of land used for agricultural practices (Ministry of Agriculture 2016). Despite this, Kazakhstan's agriculture accounts for only 5\% of the total GDP (The World Bank 2015b). Kazakhstan's importation of food is very high (approximately 40\% of its needs), mainly because of the slow development of the agro-sector. The main objective of the state agriculture programs is to maintain food security of the country based on competitive production (Zhanabaeva 2015). In recent years, the total grain crop cultivation (wheat, barley, corn, rice, oat, rye, and buckwheat) employed more than $80 \%$ of the cultivated land. Kazakhstan produced approximately 6.4-29.8 million tons of grain crops with an average grain yield of 0.5-1.7 $\mathrm{t} / \mathrm{ha}$ (Ministry of National Economy of the Republic of 
Kazakhstan Committee on Statistics 2016, data from 1990-2016). For example, the highest production year of grains was 1992 with 29.8 million tons, and the lowest production year was 1998 with 6.4 million tons. Total grain production of 2016 was 20.6 million tons. Akmola, Kostanay, and North-Kazakhstan regions are the three major grain-producing regions in Kazakhstan (70-80\%). In addition to grains, production of vegetables, potatoes, and oilseeds was 3.6, 3.5, and 1.5 million tons, respectively (Ministry of National Economy of the Republic of Kazakhstan Committee on Statistics 2016).

The Government of Kazakhstan is attempting to change mono-cropping (wheat) in Kazakhstan to more diverse crop production by developing programs. Within the state program "Agrobusiness 2020," the expansion of fields planted with soybeans is expected to reach 200,000 ha in 2017 , with future expansion to 400,000 ha (Ministry of Agriculture of Kazakhstan 2013). Another small but systematic program "MaJiKo" also exists, describing steps from the initial cultivation of oil crops to price policy, financing, processing, and further realization (Serikov 2012).

\section{SOYBEAN PRODUCTION IN KAZAKHSTAN}

Soybeans originated in the East Asian countries, including
China, Korea, and Japan. This crop was first consumed in China and other Asian countries in the form of various types of foods, such as tofu, soymilk, fermented soybean, soybean sprouts, and soy sauces (Hymowitz 1970). Soybeans began spreading to Western countries in the beginning of $20^{\text {th }}$ century, where people made use of "nature's miracle protein" in a wide range of products; animal feed to the production of industrial paints (Prodohl 2010).

In Kazakhstan, farmers began to cultivate soybeans in the 1930s; however, because of the lack of varieties and proper cultivation practices, further cultivation was abandoned. In the mid-1960s, several soybean cultivars from other countries were introduced. Statistical data on soybean production registered since 1992 by FAO revealed a gross production of 11,800 tons (Shurtleff and Aoyagi 2008).

The soybean cultivation area has been growing steadily in Kazakhstan in the recent years. In the 2000s, soybeans occupied 3,500 ha, in 2013 approximately 103,000 ha, and in 2014 around 116,000 ha of fields in Kazakhstan. Soybean production grew from 3,900 $\mathrm{t}$ in 2000 to 217,900 $\mathrm{t}$ in 2014 (Fig. 2). Its yield per hectare was $1.3 \mathrm{t} / \mathrm{ha}$ in 2000, which increased to $2.06 \mathrm{t} / \mathrm{ha}$ in 2014 (FAO 2014).

\section{CURRENT SOYBEAN DEMAND AND SUPPLY IN KAZAKHSTAN}

None of the soy food, such as tofu, natto, soymilk, or

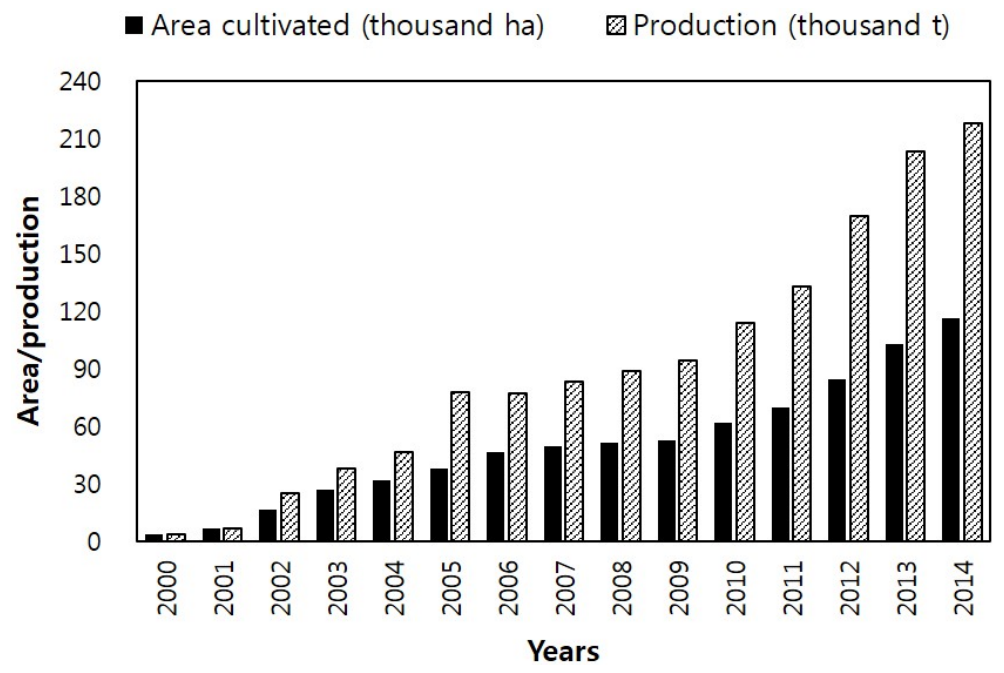

Fig. 2. Soybean cultivation area and production in Kazakhstan (FAO 2014). 
sprouts is widely used in Kazakhstan. Historically, domesticated animals have been the major source of food, clothing, and transportation for households in Kazakhstan. For Kazakh people, meat and milk are the first sources of protein in their diets. The superior animal domestication in Kazakhstan can be explained by the country's climatic properties. Animal proteins are necessary for areas with freezing temperatures, because they aid in warming the human body. Soybean is an alternative forage crop that can be utilized as animal feed and several soybean genotypes have been reported to potential to produce quality forage (Lee et al. 2014; Asekova et al. 2016a). Such genotypes can be grown as a forage crop for animal feed in
Kazakhstan.

Development of livestock and poultry production in Kazakhstan requires a highly nutritious fodder crop. Currently, soybean meal is used as feed in poultry and livestock production. Soybean meal is attractive because of the rich chemical composition of seeds, having abundant proteins and carbohydrates. There are over fifty poultry organizations operating in twelve regions of Kazakhstan, and around 9,368 livestock Agricultural Enterprises (GOK and The World Bank 2004). However, the country's soybean production does not fulfill the poultry and livestock needs. In 2009, soybean production was 80,000 tons, whereas the proposed demand was $>200,000$ tons. It

Table 1. Domestic and foreign soybean varieties successfully introduced in the Republic of Kazakhstan (Abugalieva and Didorenko 2016b).

\begin{tabular}{|c|c|c|c|}
\hline \multirow{2}{*}{ Regions } & \multirow{2}{*}{$\begin{array}{l}\text { Maturity } \\
\text { groups } s^{\mathrm{z}}\end{array}$} & \multicolumn{2}{|c|}{ Accepted varieties in the territory of Republic of Kazkhstan } \\
\hline & & Developed in Kazakhstan & Introduced from foreign countries \\
\hline Pavlodar & 000-00 & - & Anastasiya $^{\mathrm{y}, \mathrm{r})}$ \\
\hline Akmola & 000-00 & - & Anastasiya $^{\mathrm{y}, \mathrm{r})}$, SibNIIK $315^{\mathrm{y}, \mathrm{s})}$ \\
\hline Aktobe & $00-0$ & - & Bilyavka $^{\mathrm{y}, \mathrm{r})}$ \\
\hline Kostanay & 0 & - & Bilyavka $^{\mathrm{y}, \mathrm{r})}, \operatorname{SibNIIK} 315^{\mathrm{y}, \mathrm{s})}$ \\
\hline East-Kazakhstan & 00-I & Zhalpaksai $^{\text {w) }}$ & $\begin{array}{l}\text { Annushka }^{\mathrm{y}, \mathrm{r})}, \text { Avrora }^{\mathrm{x}, \mathrm{s})}, \text { Desna }^{\mathrm{w}, \mathrm{r})} \text {, } \\
\text { Korsak }^{\mathrm{u}, \mathrm{r})}\end{array}$ \\
\hline Karagandy & $0-\mathrm{I}$ & - & Annushka ${ }^{\mathrm{y}, \mathrm{r})}$, SibNIIK $315^{\mathrm{y}, \mathrm{s})}$ \\
\hline West-Kazakhstan & I-II & - & Volgogradka $1^{\mathrm{t}, \mathrm{s})}$ \\
\hline Kyzylorda & I-II & $\begin{array}{l}\text { Almaty }^{(\mathrm{w})} \text {, Zhalpaksai }{ }^{\mathrm{w})}, \text { Misula }^{\mathrm{w})} \text {, } \\
\text { Kazakhstanskaya } 2309^{t)}\end{array}$ & Anastasiya $^{\mathrm{y}, \mathrm{r})}$ \\
\hline \multirow[t]{3}{*}{ Almaty } & I-III & Almaty $^{\mathrm{w})}$, Zhalpaksai ${ }^{\mathrm{w})}$, Misula ${ }^{\mathrm{w})}$, Perizat ${ }^{\mathrm{v})}$ & Anastasiya $^{\mathrm{y}, \mathrm{r})}$ \\
\hline & & 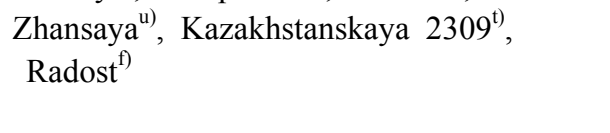 & $\begin{array}{l}\text { Tanais }^{\mathrm{w}, \mathrm{r})}, \text { Terek }^{\mathrm{w}, \mathrm{r})}, \text { Cheremosh }^{\mathrm{w}, \mathrm{r})} \\
\text { Vilana }^{\mathrm{v}, \mathrm{s})}, \text { Zen }^{\mathrm{u}, \mathrm{q})}, \text { Renta }^{\mathrm{v}, \mathrm{s})}, \text { Sava }^{\mathrm{u}, \mathrm{q})} \\
\text { Selekta } 302^{\mathrm{v}, \mathrm{s})}\end{array}$ \\
\hline & & Evrika $^{\mathrm{u}}$, Lastochka ${ }^{\mathrm{t}}$ & $\begin{array}{l}\text { Ana }^{\mathrm{u}, \mathrm{q})}, \text { Bukuriya }^{\mathrm{t}, \mathrm{q})}, \\
\text { Korsak }^{\mathrm{u}, \mathrm{r})}, \text { Voevodzhanka }^{\mathrm{u}}{ }^{\mathrm{u}, \mathrm{q}, \mathrm{q})} \\
\text {, Ruzhica }\end{array}$ \\
\hline Zhambyl & II-III & $\begin{array}{l}\text { Kazakhstan } 2309^{\text {t) }}, \text { Radost }^{\left(t^{\prime}\right.}, \text { Evrika }{ }^{\text {u) }} \\
\text { Lastochka }^{\text {t) }}\end{array}$ & Bilyavka $^{\mathrm{t}, \mathrm{r})}$, Cheremosh $^{\mathrm{w}, \mathrm{r})}$, Korsak $^{\mathrm{u}, \mathrm{r})}$ \\
\hline South-Kazakhstan & II-III & $\begin{array}{l}\text { Almaty }^{\mathrm{w})}, \text { Zhalpaksai }^{\mathrm{w})}, \text { Misula }^{\mathrm{w})}, \text { Vita }^{\mathrm{v})} \\
\text { Lastochka }^{\mathrm{t})}\end{array}$ & $\operatorname{Terek}^{\mathrm{w}, \mathrm{r})}$, Cheremosh $^{\mathrm{w}, \mathrm{r})}$ \\
\hline
\end{tabular}

\footnotetext{
${ }^{z)}$ Recommended maturity group for each cultivation region.

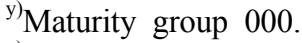

${ }^{\mathrm{x})}$ Maturity group 00 .

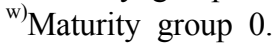

${ }^{\mathrm{v})}$ Maturity group I.

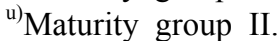

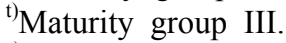

${ }^{\mathrm{s})}$ Cultivar introduced from Russia.

${ }^{\mathrm{r})}$ Cultivar introduced from Ukraine.

${ }^{\mathrm{q})}$ Cultivar introduced from Serbia.
} 
has been predicted that the demand may grow to 500,000 tons in several years (The Kazakh Telegraph Agency 2010). Additionally, there are large soybean processing factories with a production of 150,000 tons per year. The factories produce soybean milk, tofu, soybean flour, soybean yogurt, and compound feeds. However, these production units still under-produce because of the shortage of soybeans to process (Dautkanov 2015). In part, the shortage is caused by exportation to other countries by soybean producers (The Kazakh Telegraph Agency 2010). Pleasant-tasting soybean byproducts are yet to be introduced as supplementary sources of proteins and oils to human diets in the region.

\section{BARRIERS TO THE ENHANCEMENT OF SOYBEAN PRODUCTION}

\section{Lack of suitable varieties}

Cultivars adapted only for southern regions of Kazakhstan have been developed and hence farmers from the northern region are mostly dependent on varieties introduced from other countries. Cultivars from Russia and Ukraine have already been tested under Kazakhstan environment and some of them were accepted for cultivation (Table 1). Varieties introduced from Russia may be more productive because of the similarity in the environmental conditions, but they are inferior to domestic cultivars in quality (Didorenko et al. 2013; Sidoryk et al. 2013; Didorenko et al. 2015; Zakieva et al. 2015; Zhunusov et al. 2015). Moreover, dependence upon the selection achievements of other countries leads to high

Table 2. Twenty soybean varieties released by Kazakh Research Institute of Agriculture and Crop production, Almaty, Kazakhstan (Didorenko and Kudaibergenov 2014b).

\begin{tabular}{|c|c|c|c|c|c|c|c|c|c|c|c|}
\hline \multirow[b]{2}{*}{ No } & \multirow[b]{2}{*}{ Variety } & \multicolumn{9}{|c|}{ Agronomic traits ${ }^{\mathrm{z}}$} & \multirow{2}{*}{$\begin{array}{c}\text { Vegetation } \\
\text { period in } \\
\text { Almaty } \\
\text { (days) }\end{array}$} \\
\hline & & $\mathrm{MG}$ & $\begin{array}{l}\mathrm{PH} \\
(\mathrm{cm})\end{array}$ & $\begin{array}{l}\text { FPH } \\
(\mathrm{cm})\end{array}$ & GT & $\mathrm{PC}$ & $\mathrm{FC}$ & $\begin{array}{c}100 \text {-seed } \\
\text { weight }(\mathrm{g})\end{array}$ & $\begin{array}{c}\text { Protein } \\
(\%)\end{array}$ & $\begin{array}{l}\text { Oil } \\
(\%)\end{array}$ & \\
\hline 1 & Misula 1092 & 0 & $100-110$ & $13-15$ & I & Gray & Purple & $15.0-15.5$ & $40-41$ & 19.0 & $105-107$ \\
\hline 2 & Evrika 357 & II & $110-115$ & $13-15$ & I & Gray & White & $16.0-16.5$ & $36-37$ & 20.0 & $125-127$ \\
\hline 3 & $\begin{array}{l}\text { Kazakhstanskaya } \\
2309\end{array}$ & III & $125-140$ & $15-17$ & I & Gray & White & $15.5-16.0$ & $38-40$ & 19.0 & $125-127$ \\
\hline 4 & Zhalpaksai & 0 & $90-110$ & $10-11$ & I & Gray & White & $16.0-17.0$ & $38-40$ & 19.0 & $105-112$ \\
\hline 5 & Almaty & 0 & $65-80$ & $10-11$ & $\mathrm{D}$ & Tawny & White & $18.0-18.5$ & $38-40$ & 19.0 & $107-112$ \\
\hline 6 & Vita & I & $110-120$ & $10-13$ & I & Gray & White & $15.5-16.5$ & $39-40.5$ & 21.0 & $117-123$ \\
\hline 7 & Lastochka & III & $90-100$ & $13-15$ & SD & Gray & White & $17.0-17.5$ & 39.0 & 19.0 & $127-133$ \\
\hline 8 & Radost & III & $115-125$ & $10-12$ & I & Tawny & White & $16.0-16.5$ & $39-40$ & 19.0 & $127-133$ \\
\hline 9 & Zhansaya & II & $95-105$ & $7-10$ & $\mathrm{D}$ & Tawny & Purple & $17.0-17.5$ & $40-41$ & 19.0 & $120-125$ \\
\hline 10 & Perizat & I & $95-105$ & $10-12$ & SD & Gray & Purple & $16.5-17.0$ & $41-42$ & 19.0 & $117-120$ \\
\hline 11 & Nina & I & $100-110$ & $10-12$ & I & Gray & White & $17.5-18.0$ & $39-40$ & 19.0 & $115-120$ \\
\hline 12 & Nadezhda & III & $115-130$ & $12-15$ & I & Tawny & Purple & $16.5-17.5$ & $38-39$ & 19.0 & $130-140$ \\
\hline 13 & Riza & II & $110-120$ & $12-15$ & I & Gray & Purple & $18.0-18.5$ & $40-41$ & 19.0 & $125-127$ \\
\hline 14 & Iskra & I & $95-105$ & $6-8$ & I & Gray & White & $17.5-18.0$ & 39.5 & 19.5 & $110-115$ \\
\hline 15 & Bolashak 2030 & I & $100-120$ & $10-12$ & I & Gray & Purple & $17.5-18.0$ & $39-40$ & 22.2 & $120-126$ \\
\hline 16 & Roza & I & $105-120$ & $13-15$ & I & Gray & Purple & $15.0-16.5$ & 38.9 & 21.2 & $114-117$ \\
\hline 17 & Sabira & II & $95-105$ & $10-12$ & SD & Tawny & Purple & $15.0-16.5$ & $36-38$ & 20.5 & $123-127$ \\
\hline 18 & Zara & 0 & $95-110$ & $10-12$ & $\mathrm{D}$ & Tawny & White & $15.5-16.5$ & $40-41$ & 19.5 & $102-105$ \\
\hline 19 & Danaya & II & $105-125$ & $13-15$ & I & Gray & Purple & 16.5 & $37-39$ & 19.5 & $123-127$ \\
\hline 20 & Sulamit & II & $115-125$ & $13-15$ & SD & Gray & Purple & $18.0-18.5$ & $40-41$ & 19.5 & $123-127$ \\
\hline
\end{tabular}

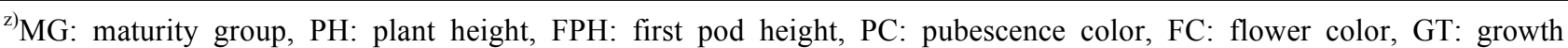
type - I (indeterminate), D (determinate), and SD (semi-determinate). 
production costs. Breeders from the Kazakh Institute of Agriculture and Plant Production developed approximately 20 domestic soybean varieties (Table 2), 10 of which were approved for use in the territory of Kazakhstan, whereas the remaining varieties are still being tested by the State Commission (Abugalieva et al. 2013; Zakieva et al. 2015).

Soybean breeders face challenges in the adaptation to Kazakhstan's long photoperiod and abiotic stresses. Because the northern region is located at higher latitudes, it is characterized by long day length, more harsh winters, and a shorter growth period. Therefore, expansion of soybeans requires the development of "climate smart" varieties, adapted to long-day hours and to environmental conditions. Varieties in the maturity group 00-II are acceptable for cultivation in the regions of Kazakhstan. Varieties with maturity periods of 80-95 days ( 000 and 00 maturity groups) are acceptable for northern regions, and those with maturity periods of 80-120 days are suitable for successful cultivation in the southern regions of Kazakhstan (Zakieva et al. 2015). Additionally, farmers share their preferences for certain phenotypes of crops, such as longer distances from plant base to the first node on the main stem, and shattering resistance.

Repinsky et al. (2011) reported that breeders in developing countries place importance on plant genetic resources. Typically, landraces must be utilized as a source of alleles for important domestication-related traits. Kazakhstan scientists have published their report results on testing and selection of soybean landraces. Early maturing landraces were collected from the Kazakh Scientific Research Institute of Agriculture and Plant Production in the Almaty region and were placed in field trials for further selection at the Kostanay (north) and East Kazakhstan (east) Research Institutes (Didorenko et al. 2013; Didorenko et al. 2015). Didorenko et al. (2013) reported that F2 populations developed from crosses involving high yielding and early maturing accessions, k589529, k588963, k5582, k36598-217, Omskaya 4 and Nika, from Russia and domestic cultivars, Lastochka, Zhansaya, and Almaty, have been sent to the East Kazakhstan Research Institute for further testing and cultivar development.

Financial shortages, inadequate access to laboratories with advanced breeding technologies, poor access to the current literature, and absence of knowledge of joint technologies for breeding limits the improvements in plant breeding, eventually leading to dependence on foreign varieties (Iskakov 2004). It has been noted that crop varieties developed in other countries do not adapt to the conditions in Kazakhstan. There are approximately 60 unique natural zones in the republic for which cultivars need to be developed (Didorenko et al. 2015). Prerequisite, for successful soybean adaptation with traits of high productivity, premium quality under abiotic factors, is competency in genetic and molecular resources of the crop.

\section{Poor genetic and molecular resources}

Because of diversification programs for agricultural crops in Kazakhstan, significant attention is paid to oil crops, legumes, and groats. Currently, there is a substantial effort in Kazakhstan to establish a National Gene Pool. From 2001 to 2014, the Kazakh Institute of Agriculture and Crop Production (Almaty, Almalybak) examined documentation, and storage of a soybean gene pool. Accessions from all research institutions in Kazakhstan were registered and compiled into an "indicative catalog of soybean collections" (Didorenko and Kudaibergenov 2014a). The catalog consisted of 552 accessions and cultivars from different origins: Kazakhstan, Russia, China, Canada, USA, Ukraine, Belarus, Moldova, Poland, Sweden, Hungary, Serbia, France, Czech-Slovak, Belgium, Japan, Uzbekistan, and Kyrgyzstan. All the accessions were categorized by maturity group (000-III MG). Although the majority of the germplasm collection was from Russia (330), 53, 52, and 43 accessions from the Ukraine, Canada, and Kazakhstan, respectively, were also included.

The various accessions and landraces may have necessary alleles contributing to agriculturally important traits. Recent advances in molecular marker technology have facilitated allele mining and gene discovery to aid in the genetic dissection of key traits (Niu et al. 2013; Asekova et al. 2016b; Kulkarni et al. 2016; Kulkarni et al. 2017). Maturity is one such trait that has substantial significance in the development of cultivars suitable for the environmental conditions in Kazakhstan. Molecular markers linked to genes/alleles for maturity traits have been developed for soybeans (Watanabe et al. 2009; Watanabe et al. 2011; Xia 
et al. 2012; Tsubokura et al. 2013). Such markers are of substantial value in the selection and can be utilized to screen different accessions/landraces to reveal the corresponding alleles. In one such study, Abugalieva et al. (2016a) screened 120 soybean accessions for major $E$ genes $(E 1, E 2, E 3$, and $E 4)$ to reveal the alleles controlling maturity in these genotypes. They phenotyped 120 accessions from three different locations in the East Kazakhstan, Almaty, and Kostanay regions, and associated their agronomic performance with the $E$ genes. Genotypes of $e 1$-as/e2/E3/E4 were the most common among tested accessions. Local commercial cultivar carrying the $E 1 / e 2 / E 3 / E 4$ genotype (Zara) exhibited the highest yield in the southeastern region among all the tested accessions. Eleven accessions with the genotype $e 1$-as/e2/E3/E4 were top yielding in conditions of East Kazakhstan. Based on the type of maturity alleles, different accessions could be utilized in crosses to develop new cultivars, through marker assisted breeding.

\section{High extent of saline soils}

The total worldwide area of saline and sodic soils were estimated as 411.7 and 617.9 million ha, respectively (Squires 2009). The productive soil layers in Central Asia are highly affected by salinity, sodicity, hydromorphy, and all types of erosion. Saline soils accounted for $47.5 \%$ of all arable lands in the region (Bucknall et al. 2003).

Natural climatic conditions of arid and semi-arid zones in Kazakhstan lead to desertification and soil depletion processes like salinization, sodicity, and wind erosion. It was reported that around 30 million ha of agricultural lands are saline in Kazakhstan (Ministry of Energy of the Republic of Kazakhstan 2015). Continental climate, high rate of evapotranspiration, uneven and insufficient precipitation render farming in Kazakhstan irrigation-reliant, particularly in the southern regions.

Anthropological factors, such as unnecessary water use, together with inappropriate drainage systems and over fertilization leads to secondary salinization. Lands irrigated by surface flows of rivers in a basin of the Aral Sea of Kazakhstan and the entirety of Central Asia are facing salinity-related problems (Chembarisov and Bakhritdinov 1989; Shirokova and Morozov 2006). Approximately
$51.4 \%$ of irrigated lands in the Kazakhstan region of the Syrdariya River basin are saline, $28.7 \%$ slightly saline, $16.2 \%$ moderately saline, and $6.5 \%$ severely saline. In the entire territory of the Kazakhstan regions of Kyzylorda, Almaty, Zhambyl, and South Kazakhstan constitute the most salt-affected areas (NWG of Kazakhstan 2002).

In the northern region of the country, currently, no large-scale irrigation occurs because of sufficient natural precipitation. However, since the necessity of irrigation might occur in the future, available water sources need to be properly utilized. Besides, elevation of ground water levels should be avoided due to the high salt content of deep layers in the soils (FAO and ITPS 2015). The risk of salinization of soils in Kazakhstan requires development of cultivars with good productivity in saline conditions. Molecular markers can be used to select salt tolerant genotypes and utilize them in future breeding programs. As such, the available genetic resources need to be screened for their salt tolerance by different methods, like the "plastic container method", which was found highly effective in identifying salt tolerant plants in greenhouses, without additional expenses for chemicals or special equipment (Lee et al. 2008). In soybeans, wild relatives may have alleles that could contribute to salt tolerance (Ha et al. 2013). One major gene, GmSALT3 responsible for salt tolerance in soybeans have been reported by Guan et al. (2014). Such gene/allele can be introduced in the desired cultivar to improve their growth and performance in the sodic soils.

\section{CANDIDATE REGIONS FOR SOYBEAN EXPANSION}

Most attention is centered on Kostanay and East Kazakhstan in the northern region, Zhambyl and Almaty in the southern region of the country. Based on agricultural risk assessment, soybean cultivation was recommended in the three regions of Zhambyl, East-Kazakhstan, and Almaty by the World Bank Group (Broka et al. 2016). The northern region (North Kazakhstan and Kostanay) possesses the important resource of chernozem soil. In the southern region (Almaty and South Kazakhstan), the 
presence of foothills, more moist areas, combination of productive soils and irrigated land along the rivers are important. Two regions (Mangystau and Atyrau) on the west side, where climate and soil conditions are harsh, are not suitable for commercial agricultural production. The candidate regions for soybean expansion in Kazakhstan for the present study were selected considering the properties of the regions.

The Almaty region $\left(45^{\circ} 00^{\prime} \mathrm{N}, \quad 78^{\circ} 00^{\prime} \mathrm{E}\right)$. Natural conditions of the Almaty region include five climatic zones ranging from deserts to persistent mountain snows. The average temperature is $6-8^{\circ} \mathrm{C}$ in January and $23^{\circ} \mathrm{C}$ in July. The annual rainfall in the plains is up to $300 \mathrm{~mm}$, and in the foothills and mountains ranges from 500-600 to $1,000 \mathrm{~mm}$ per year (Fig. 3) (Meteoblue 2017). The growth period in the foothills and the plains is 205-225 days. The longest day is $15 \mathrm{~h} 23 \mathrm{~min}$ in July, and in mid-December, day length reduces to approximately to $8 \mathrm{~h} 59 \mathrm{~min}$ (Fig. 4). The main types of agriculture in the Almaty region are the production of grains, sugar beets, potatoes, soybeans, and wine making and tobacco production. Crops are planted across 907,500 ha. Today, $98 \%$ of all soybeans in Kazakhstan are produced in the Almaty region on irrigated lands (Informburo 2016). Soybeans are sown in the region on 79,300 ha with a total yield of 166,500 tons in 2012 (Sidorik 2015). The region has comparatively mild climatic conditions and irrigation facilities for wider soybean production.

The Zhambyl region $\left(44^{\circ} 00^{\prime} \mathrm{N}, 72^{\circ} 00^{\prime} \mathrm{E}\right)$. The average temperature is $-5^{\circ} \mathrm{C}$ in January and is $26^{\circ} \mathrm{C}$ in July. Annual precipitation is $400-450 \mathrm{~mm}$ in spring, and $100-200 \mathrm{~mm}$ in fall (Meteoblue 2017) (Fig. 4). Day length in mid-July reaches 15 h 20 min, and in December it is 9 h 20 min. Zhambyl is the region with fresh groundwater source in Kazakhstan. The presence of abundant water along with

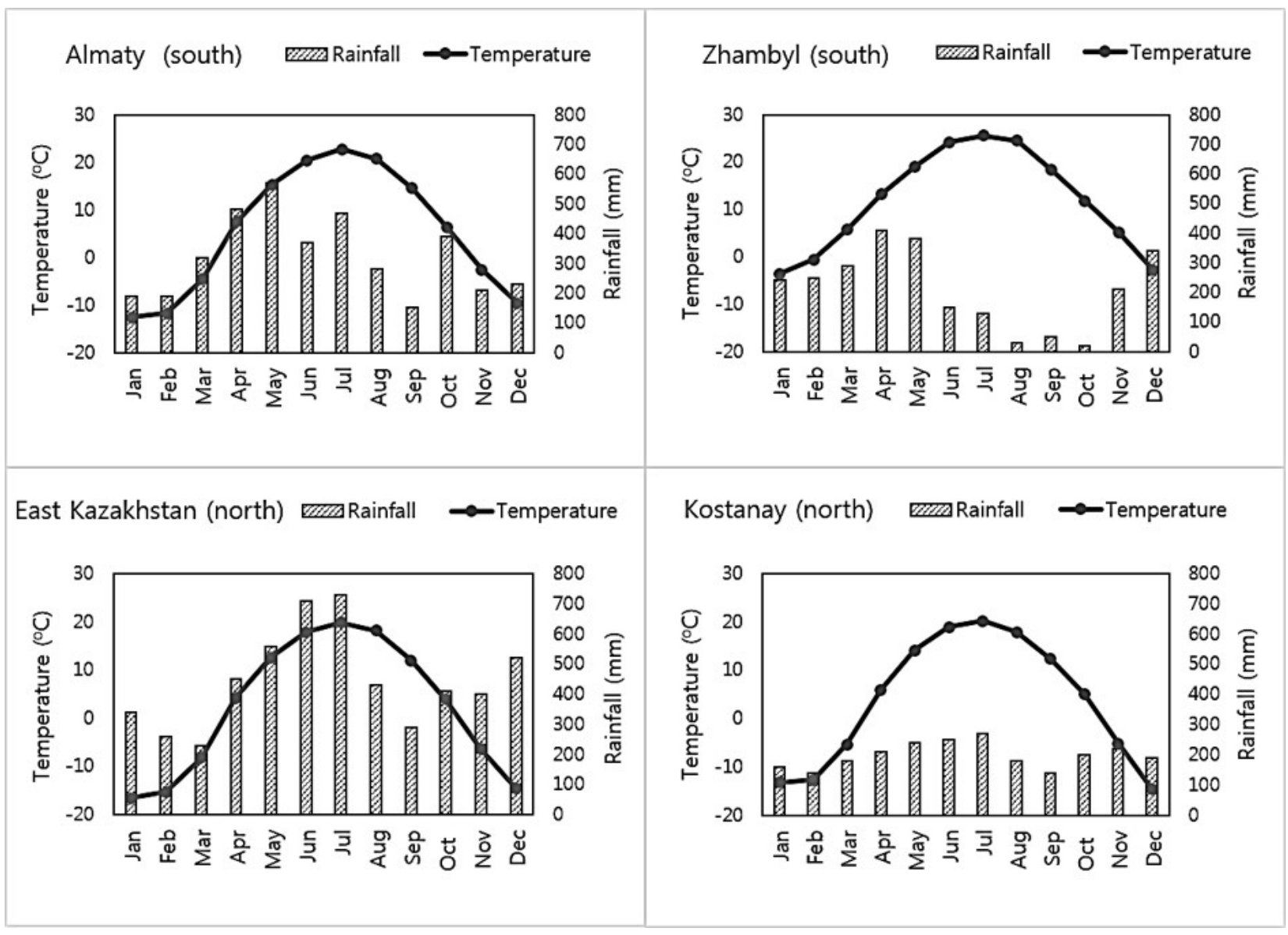

Fig. 3. Average monthly temperature and rainfall for 4 regions of Kazakhstan (averaged from 1990-2012; The World Bank 2016). 


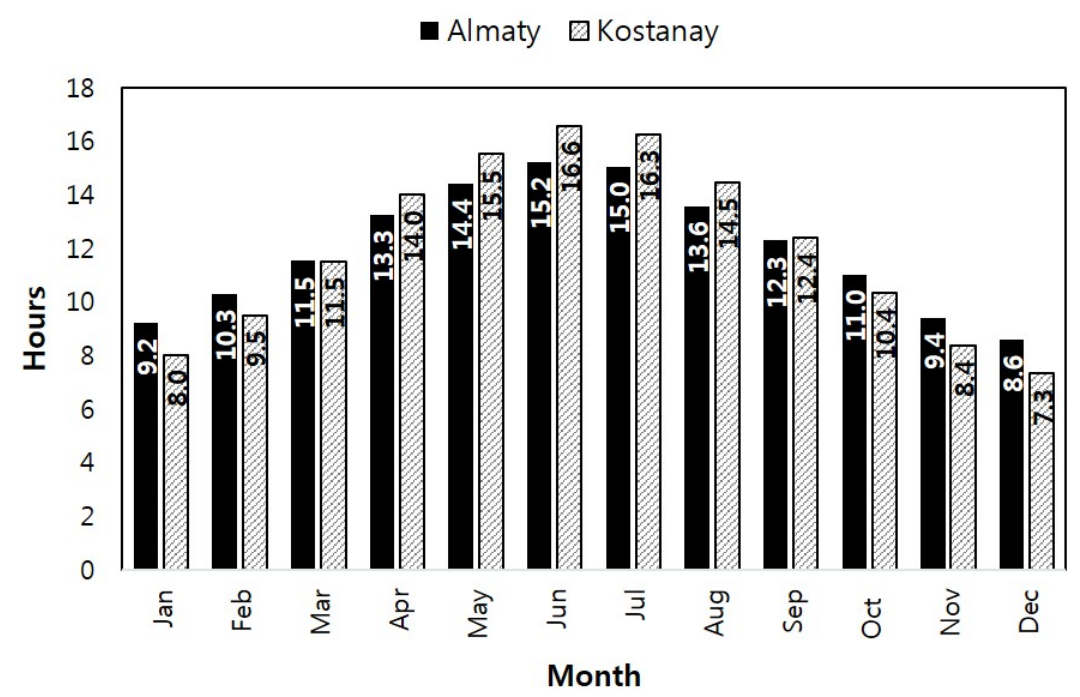

Fig. 4. Day length on the $15^{\text {th }}$ day of each month in Almaty (south, $45^{\circ} 00^{\prime} \mathrm{N}, 78^{\circ} 00^{\prime} \mathrm{E}$ ) and Kostanay (north, $53^{\circ} 12^{\prime} \mathrm{N}$, $63^{\circ} 38^{\prime} \mathrm{E}$ ) (Timeanddate 2016), showing the difference in photoperiod in the two regions.

drip irrigation systems significantly increases productivity in crops as well as acreage in production. The area of soybean production field was estimated 700 ha, with a total yield of 600 tons (Sidorik 2015).

The Kostanay region $\left(53^{\circ} 12^{\prime} \mathrm{N}, 63^{\circ} 38^{\prime} \mathrm{E}\right)$. The climate in the area is sharply continental, with hot and dry summers and cold winters with snow. In winter, the minimum temperature often drops to $-35^{\circ} \mathrm{C}$, and the maximum temperature rises up to $41^{\circ} \mathrm{C}$ in summer. The average temperature is $-19^{\circ} \mathrm{C}$ in January and $20^{\circ} \mathrm{C}$ in July. The frost-free period ranges from 108 to 130 days. Average annual temperature is $0.3-2.3^{\circ} \mathrm{C}$, which in some years increases to $4.5-5^{\circ} \mathrm{C}$ or declines to $0-1.2^{\circ} \mathrm{C}$ (Meteoblue 2017). Maximum rainfall $(250-300 \mathrm{~mm})$ occurs in the second half of summer, often in July, which would be an advantage for cultivars developed with an adjusted seed filling stage to the rainy period (Fig. 4). In July, day length index is 16 hours 56 minutes, whereas in mid-December it is 7 hours 33 minutes (Fig. 3). Total land area in the Kostanay region is 19,600 ha. The area of farmlands is $18,123,000$ ha, including $5,659,000$ ha or $31.2 \%$ of arable lands and 12,072,000 ha of (66.6\%) pastures. Total area under soybean cultivation was 400 ha, with the production of only 120 tons (Sidorik 2015).

The East Kazakhstan region $\left(49^{\circ} 57^{\prime} \mathrm{N}, 82^{\circ} 37^{\prime} \mathrm{E}\right)$. The coldest month (January) has an average monthly tem- perature of $-23^{\circ} \mathrm{C}$. Average temperature of the warmest month (July) is $17^{\circ} \mathrm{C}$. Rarely, the minimum temperature reaches $-55^{\circ} \mathrm{C}$ in winters, and in summer maximum temperature goes up to $43^{\circ} \mathrm{C}$. Precipitation is unevenly distributed during the warm period. Annual precipitation varies accordingly from 165 to $200 \mathrm{~mm}$ (in the desert and semi-desert zone) up to $800-1500 \mathrm{~mm}$ (mountainous zone). Precipitation during the warm season (April-October) is greater than that during the cold period (November-March). Winter is cold and long (5-6 months). Snow cover in the region is uneven $(15-80 \mathrm{~cm})$. In winter, most parts of the region are dominated by winds from the southeast, and during warm periods, from the northeast. The average wind speed was 2.5-3.5 m/second (Meteoblue 2017). Day length in July is 16 hours 27 minutes and 8 hours 1 minute in December. The main branch of agriculture is rain-fed cereal farming, dairy, meat, and meat-wool purposed livestock. Soybeans were cultivated over 3,100 ha field in 2012, with a gross seed yield of 2,400 tons (Sidorik 2015).

\section{CONCLUSION}

Kazakhstan has great potential in both animal and crop production with its natural resources and land. The natural diversity of country's landscape requires crops to be 
adapted to each environment. In the case of soybeans, adaptation is more challenging because of the photosensitivity of the crop. Several genes/alleles for flowering and maturity in soybeans have been identified. The next step for soybean breeders is to utilize the genetic/molecular information for breeding cultivars with optimal yield for each region. In particular, adaptation to harsher climatic conditions in northern Kazakhstan may result in better quality of soybean seed composition, resulting in superior cultivars for protein and oil content. At present, the soybean germplasm collection is very limited in Kazakhstan and hence more accessions should be introduced from East Asian countries. Because Korea, Japan, and China are the countries where soybeans originated, the accessions from these regions are likely to be genetically diverse, and therefore will provide significant genotypic and phenotypic variation when used in breeding programs. The strategic long-term crop improvement programs with adequate financial assistance from the government and application of advanced molecular breeding technologies is the way forward to enhance the soybean production in Kazakhstan.

\section{ACKNOWLEDGEMENTS}

This research was supported by Kyungpook National University Bokhyen Research Fund, 2015.

\section{REFERENCES}

Abugalieva AI, Azhgaliev TB, Zhumahanova AZh, Dolgih L. 2013. Genetic diversity of oil crops in Kazakhstan. Proc. of III Vavilov International Conference "Ideas of N.I. Vavilov in the modern world ". N.I. Vavilov Institute of Plant Genetic Resources. St. Petersburg. pp. 44-52. (In Russian).

Abugalieva S, Didorenko S, Anuarbek S, Volkova L, Gerasimova Y, Sidorik I, Turuspekov Y. 2016a. Assesment of soybean flowering and seed maturation time in different latitude regions of Kazakhstan. PLoS ONE 11: $1-12$.

Abugalieva A, Didorenko S. 2016b. Genetic diversity of soybean cultivars belonging to different ripeness groups with regard to performance and quality. Vavilov Journal of Genetics and Breeding. 3: 303-310. (In Russian with English abstract).

Asekova S, Kulkarni KP, Kim M, Kim JH, Song JT, Shannon JG, Lee JD. 2016a. Novel quantitative trait loci for forage quality traits in a cross between PI 483463 and 'Hutcheson' in soybean. Crop Sci. 56: 2600-2611.

Asekova S, Kulkarni KP, Patil G, Kim M, Song JT, Nguyen HT, Shannon JG, Lee JD. 2016b. Genetic analysis of shoot fresh weight in a cross of wild ( $G$. soja) and cultivated (G. max) soybean. Mol. Breed. 36: 103.

Bucknall J, Klytchnikova I, Lampietti J, Lundell M, Scatasta M, Thurman M. 2003. Irrigation in Central Asia social, economic and environmental considerations. The World Bank. (Online available at: http:// www.worldbank.org/en/topic/environment ).

Broka S, Giertz A, Christensen G, Rasmussen D, Morgounov A. 2016. Kazakhstan: Agricultural sector risk assessment. World Bank Group Report Number 103076-KZ. Washington DC. USA.

Chembarisov E, Bakhritdinov B. 1989. Hydrochemestry of river and drainage waters of Central Asia. Ukituvchi publisher, Tashkent, Uzbekistan. pp. 132.

Dautkanov N. 2015. Grains and oilseeds. Kazakhstan. (Online available at: https://margin.kz/news/759/pererabotka-soyabobov-perspektivna-dlya-kazahstana-ekspert/). (In Russian).

Didorenko SV, Kudaibergenov MS, Sidorik IV, Shilina Yu. 2013. Selection of ultra-early maturing soybean cultivars for northern and eastern regions of Kazakhstan. Proc. of International Scientific and Practical Conference of Young scientists and specialists. State Scientific Organization, Agricultural Research Institute of the Southeast. Saratov. Russia. pp. 69-73. (In Russian).

Didorenko S, Kudaibergenov M. 2014a. Indicative catalog of soybean collection (Glycine max. L). Ministry of Agriculture of the Republic of Kazakhstan. JSC "KazAgroInnovation". Kazakh Scientific Research Institute of Agriculture and Plant Growing. Almaty, Kazkhstan. (In Russian).

Didorenko S, Kudaibergenov M. 2014b. Soybean varieties, selected in LLP "Kazakh Research Institute of Agriculture and Plant Growing". Ministry of Agriculture of the Republic of Kazakhstan. JSC "KazAgroInnovation". Kazakh Scientific Research Institute of Agriculture and Plant Growing. Almaty, Kazkhstan. (In Russian). 
Didorenko SV, Sprygailova YuN, Kudaibergonov MS, Abugalieva AI. 2015. Selection of soybean in East Kazakhstan. Science and World. 1(28): 83-88. (In Russian).

FAO, ITPS. 2015. Status of the World's Soil Resources (SWSR)-Main Report. Nations, Food and Agriculture Organization of the United and Intergovernmental Technical Panel on soils. Rome, Italy.

FAO. 2014. Crops. (Online available at: http://www.fao.org/ faostat/en/\#data/QC).

Frenken K. 2012. Irrigation in Central Asia in figures. FAO Water Reports 39, AQUASTAT Survey. Rome, Italy.

Guan R, Qu Y, Guo Y, Yu L, Liu Y, Jiang J. et al. 2014. Salinity tolerance in soybean is modulated by natural variation in GmSALT3. The Plant Journal. 80: 937-950.

GOK and The World Bank. 2004. Kazakhstan's livestock sector-supporting its revival. The Government of Kazakhstan and the World Bank. A joint sector work of the joint economic research program. Washington, USA.

Ha BK, Vuong TD, Velusami V, Nguyen HT, Grover JS, Lee JD. 2013. Genetic mapping of quantitative trait loci conditioning salt tolerance in wild soybean (Glycine soja) PI 483463. Euphytica. 193: 79-88.

Hymowitz T. 1970. On the domestication of soybean. Econ. Bot. 24: 408-421.

IPhO. 2014. General Information about Kazakhstan. (Online available at: http://ipho2014.kz/content/view/1/242 ). (In Russian).

Iskakov A. 2004. National Plant Breedin Survey. National Center for Biotechnology. Astana, Kazakhstan.

Informburo. 2016. Kazakhstan's soybean will be sold to China. (Online available at: https://informburo.kz/novosti/ kazahstanskuyu-soyu-budut-prodavat-kitaycam-.html). (In Russian).

Kulkarni KP, Kim M, Grover JS, Lee JD. 2016. Identification of quantitative trait loci controlling soybean seed weight in recombinant inbred lines derived from PI 483463 (Glycine soja) x 'Hutcheson' (G. max). Plant Breeding. 135: 614-620.

Kulkarni KP, Asekov S, Lee DH, Bilyeu K, Song JT, Lee JD. 2017. Mapping QTLs for 100-seed weight in an interspecific soybean cross of Williams 82 (Glycine max) and PI 366121 (Glycine soja). Crop Pasture Sci. 68: 148-155. Lee JD, Smothers SL, Dunn D, Villagarcia M, Shumway CR, Carter TE Jr., Shannon JG. 2008. Evaluation of a simple method to screen soybean genotypes for salt tolerance. Crop Sci. 48: 2194-2200.

Lee EJ, Choi HJ, Shin DH, Kwon CH, Shannon JG, Lee JD. 2014. Evaluation of forage yield and quality for the accessions derived from inter-specific cross between wild and cultivated soybeans. Korean J. Breed. Sci. 46: 66-77.

Meteoblue. 2017. Archive/Climate. (Online available at: https://www.meteoblue.com ). (In Russian).

Ministry of Agriculture of Kazakhstan. 2013. Program for the development of Agribusiness in the Republic of Kazakhstan in 2013-2020 “Agrobusiness-2020”. (Online available at: http://mgov.kz/proekt-programmy-porazvitiyu-apk-v-respubliki-kazahstan-na-2013-2020-god y/ ). (In Kazakh).

Ministry of Agriculture. 2016. Ministry of Agriculture of the Republic of Kazakhstan. (Online available at: http:// mgov.kz/en/napravleniya-razvitiya/rastenievodstvo/). (In Russian).

Ministry of Energy of the Republic of Kazakhstan. 2015. Draft National report on the state of the environment and use of natural resources for 2015. (Online available at: http://ecodoklad.kz/zemelnye-resursy ). (In Russian).

Ministry of National Economy of the alieve Republic of Kazakhstan Comitee on statistics. 2016. (Online available at: http://www.stat.gov.kz/faces/wcnav_externalId/ publicationsPage?_afrLoop $=13717964570722633 \# \% 40$ \%3F_afrLoop\%3D13717964570722633\%26_adf.ctrl-st ate\%3Dtxyznw2a9_80). (In Kazakh).

Niu Y, Xu Y, Liu XF, Yang SX, Wei SP, Xie FT, Zhang YM. 2013. Association mapping for seed size and shape traits in soybean cultivars. Mol. Breed. 31: 785-794.

NWG of Kazakhstan. 2002. Draft National Policy, strategy and action programs on water and salts management. GEF agency of the IFAS. Almaty, Kazakhstan.

OCHA. 2012. United Nations Office for the Coordination of Humanitarian Affairs. (Online available at: http://www. unocha.org/where-we-work/all-countries).

Prodohl I. 2010. "A Miracle bean": how soy conquered the west, 1909-1950, p. 111-132. In: Bulletin. German Historical Institute, Washington DC, USA.

Repinsky LS, Hayes KH, Miller JK, Trexler CJ, Bliss FA. 2011. Plant breeding graduate education: opinions about critical knowledge, experience, and skill requirements from public and private stakeholders worldwide. Crop Sci. 51: 2325-2336. 
Saparov A. 2014. Soil Resources of the Republic of Kazakhstan: Current status, problems and solutions, p. 61-73. In: Mueller L et al. (eds.). Novel Measurement and Assessment Tools for Monitoring and Management of Land and Water Resources in Agricultural Landscapes of Central Asia, Environmental Science and Engineering. Springer International Publishing, Switzerland.

Serikov D. 2012. Kazakhstan: "MaJiKo" is the food corporation in soybean and corn market-Evniev. Kazakh Zerno. (Online available at: http://www.kazakh-zerno.kz/ novosti/intervyu/180860-kazakhstan-mazhiko-eto-prodk orporatsiya-na-rynke-soi-i-kukuruzy-evniev). (In Russian).

Shirokova Y, Morozov A. 2006. The salinity of irrigated lands of Uzbekistan: causes and present state, p. 249-259. In: Ajmal Khan M (ed.). Sabkha Ecosystems. Volume II: West and Central Asia. Springer, Dordrecht, Netherlands. Shurtleff W, Aoyagi A. 2008. History of soybeans and soyfoods in Central Asia (1876-2008): An extensively annotated bibliography and sourcebook. Soyinfo Center, Lafayette, USA.

Sidoryk IV, Kozhakhmetov AS, Didorenko SV. 2013. Ecological variety trial of soybean in Kostanai Agricultural Institute. Proc. of VII International Conference of Young Scientists and Specialists. All-Russia Research Institute of Oil Crops by V.S. Pustovoit. Krasnodar, Russia. pp. 199-203. (In Russian with English abstract).

Sidorik IV. 2015. Soybean: biology and technology. AgroInfo. (Online available at http://agroinfo.kz/soyabiologiya-i-texnologiya/). (In Russian).

Squires VR, Glenn EP. 2009. Salination, desertification, and soil erosion, p. 102-123. In: VR. Squires (ed.) The Role of Food, Agriculture, Forestry and Fisheries in Human Nutrition. Eolss Publishers Company Limited, Oxford, UK.

The Kazakh Telegraph Agency. 2010. Selling Kazakhstan's soybean leads to food insecurity among CU member countries. Diapazon, Aktobe, Kazakhstan. (Online availabe at: http://www.diapazon.kz/kazakhstan/kazeconomy/24217-prodazha-kazakhstanskojj-soi-podryva et.html). (In Russian).

The World Bank. 2015a. Land area Kazakhstan. (Online available at: http://data.worldbank.org/indicator/AG.LND. TOTL.K2?locations=KZ).

The World Bank. 2015b. Agriculture, value added (\% of
GDP) (Online available at: http://data.worldbank.org/ indicator/NV.AGR.TOTL. ZS?locations=KZ).

The World Bank. 2016. (Online available at: http://sdwebx. worldbank.org/climateportal/index.cfm?page $=$ country historical climate\&ThisCCode=KAZ).

Timeanddate. 2016. Sunrise and Sunset Calculator. (Online available at: http://www.timeanddate.com/sun/ ).

Tsubokura Y, Matsumura H, Xu M, Liu B, Nakashima H, Anai $\mathrm{T}$ et al. 2013. Genetic variation in soybean at the maturity locus $E 4$ is involved in adaptation to long days at high latitudes. Agronomy. 3: 117-134.

Watanabe S, Hideshima R, Xia Z, Tsubokura Y, Sato S, Nakamoto Y et al. 2009. Map-based cloning of the gene associated with the soybean maturity locus E3. Genetics. 182: $1251-1262$

Watanabe S, Xia Z, Hideshima R, Tsubokura Y, Sato S, Yamanaka $\mathrm{N}$ et al. 2011. A map-based cloning strategy employing a residual heterozygous line reveals that the GIGANTEA gene is involved in soybean maturity and flowering. Genetics. 188: 395-407.

Xia Z, Watanabe S, Yamada T, Tsubokura Y, Nakashima H, Zhai $\mathrm{H}$ et al. 2012. Positional cloning and characterization reveal the molecular basis for soybean maturity locus E1 that regulates photoperiodic flowering. Proc. Natl. Acad. Sci. USA. 109: E2155-E2164.

Zakieva AA, Iskakov AR, Kudaibergenov MS. 2015. Main questions of soybean proliferation in Northern parts of Kazakhstan. Modernization of economic systems: looking to the future, Collection of scientific papers. Vědecko vydavatelské centrum «Sociosféra-CZ», Praha, Czech Republic. pp. 306-308. (In Russian).

Zhanabaeva Zh. 2015. Current status of agricultural sector in Republic of Kazakhstan. (Online available at: http://group-global.org/ru/publication/18972-sovremenn oe-sostoyanie-agrarnogo-sektora-respubliki-kazahstan). (In Russian).

Zhunusov AE, Galiev ZhM, Taskulova AM, Shoiko VV. 2015. Soybean-as an important forage crop and its production under conditions of North Kazakhstan region. Proc. of 3rd International scientific-practical conference "Actual problems of science and education in the field of natural and agricultural sciences". Petropavlovsk, Kazakhstan. pp. 34-37. (In Russian). 